\title{
1. Introduction: The Aristotelian Monetary Tradition
}

\author{
Edward W. Fuller
}

It is impossible to overstate the significance of Aristotle in the history of monetary thought. Of course, Aristotle did not give posterity a complete theory of money. But every major contribution to monetary thought in the history of economic science has been built on the foundation laid by Aristotle. At its core, the modern theory of money is an Aristotelian theory of money. Thus it is impossible to fully understand monetary theory today without understanding its Aristotelian origins.

Aristotle (384-22 BC) was born in Stagira, Macedonia, or what is today northern Greece. Aristotle's father, Nichomachus, was physician to the king of Macedonia. Aristotle went to Athens in 367 and studied in Plato's Academy for 20 years. He left Athens after Plato's death in 347 and became tutor to Alexander the Great. In 334, he returned to Athens and founded his own school, the Lyceum. He stayed at the Lyceum until just before his death. He was forced to flee Athens after the death of Alexander the Great in 323, and he died on the island of Euboea of natural causes in 322 .

Unfortunately, Aristotle's philosophy was lost in the West after the sixth century. As legend has it, Emperor Justinian shut down the pagan schools of philosophy in 529 AD, and the pagan philosophers fled east with Aristotle's works. Knowledge of Aristotle's works was only regained in the West after the First Crusade (1095-99), which restored contact between the East and West. Eventually, ancient Greek and Arabic versions of Aristotle's works found their way to Europe. The recovery of Aristotle's thought is generally placed from about 1150 to about 1250. The reintroduction of Aristotle in the West ignited the greatest intellectual revolution in the history of humankind. No doubt, it was the recovery of Aristotle that set the stage for the Renaissance - the rebirth of reason in Europe.

Initially, the Catholic Church saw Aristotle as a threat. He had argued that the Earth was uncreated and eternal, and this contradicted the account of creation found in the Bible. The church initially banned Aristotle's works. But his monumental system of philosophy was too powerful to be ignored. Soon enough, the church realized that the proper course was to reconcile Aristotelianism with Catholicism. Albert the Great (c. 1200-80) and Thomas Aquinas (1225-74) were the best minds in Europe, and they got to work harmonizing Aristotelianism with Catholicism. More than anyone else, these two men were responsible for bringing Aristotle back to the West. In this way, Albert and Aquinas opened the door for the Renaissance.

Aristotle's writings on money are contained in two works: the Nicomachean Ethics and the Politics. A work called Economics was attributed to Aristotle in the Middle Ages, but the work is not authentic and is not about economic science. The Nicomachean Ethics and the 
Politics must be considered the germs of the modern theory of money. Thus it is necessary to understand the history of these works and their translations.

The Nicomachean Ethics was not written for publication but was rather a set of notes from Aristotle's lectures. It is a revision of his earlier work, the Eudemian Ethics (c. 350 BC). Book $\mathrm{V}$ of the Nicomachean Ethics, which contains his material on money, is identical to Book IV of the Eudemian Ethics. Still, the Eudemian Ethics was not translated into Latin until long after the Nicomachean Ethics, meaning the Nicomachean Ethics is the relevant work for those interested in the history of economic thought.

Robert Grosseteste (1175-1253) completed the Latin translation of the Nicomachean Ethics by 1247. Unfortunately, Grosseteste's translation was problematic, and it created much trouble for Aristotle's medieval interpreters. Importantly, Grosseteste mistranslated the Greek word chreia into the Latin opus, meaning "work" or "labor." However, chreia means "need," while the Greek for "work" is ergon. Grosseteste was aware of the issue. In his notes, he also translated chreia into the Latin utilitas, meaning "utility," and the Latin indigentia, meaning "need" or "demand." Still, Grosseteste translated chreia as "work" in his translation of the Nicomachean Ethics. Grosseteste's mistranslation of chreia made it seem as though Aristotle had a labor theory of value.

Albert the Great is perhaps the most underappreciated figure in the history of monetary thought. He is best remembered as Aquinas's master, but Aquinas did not advance beyond Albert's work on money. In fact, Albert's commentaries were far more influential than Aquinas's with early monetary thinkers. Shockingly, Albert's writings on money are still available only in Latin.

Albert obtained a copy of Grosseteste's translation in 1248, and he produced two commentaries on the Nicomachean Ethics in the following decades. Albert's First Commentary was completed around 1252, and it set the pattern for commentaries by Aquinas and others. Albert is often wrongly associated with the labor theory of value because of his First Commentary. As noted, however, Grosseteste was responsible for injecting the labor theory into Aristotle, not Albert. Albert finished his Second Commentary around 1262, and this work cleared up the confusion over the word chreia. Here Albert established the meaning of chreia as the Latin indigentia, meaning "need" or "demand." Thus the Second Commentary contains the Aristotelian utility theory of value, not the labor theory. Albert deserves much credit for putting value theory back on track after Grosseteste. Following Albert, no medieval economic thinker argued that labor was the sole determinant of value.

Aquinas wrote his commentary on the Nicomachean Ethics in 1271. Aquinas's commentary is very similar to Albert's Second Commentary, and his goal was to clarify. His main contribution was to popularize the monetary thought of Aristotle and Albert. Along with Albert, Aquinas played the key role in establishing the utility theory of value in medieval economics. Aristotle's Nicomachean Ethics and the commentaries by Albert and Aquinas contain the seeds of the modern theory of supply and demand. The quantity theory of money is the application of the theory of supply and demand to money. It is the most elementary proposition in the theory of money, and its history begins with Aristotle's Nicomachean Ethics and the commentaries of Albert and Aquinas.

Aristotle's Politics is the other foundational work in the history of monetary thought. Aristotle developed the Politics after his work on ethics, and it dates to around $350 \mathrm{BC}$. It contains more commentary on money than the Nicomachean Ethics. In the Nicomachean 
Ethics, Aristotle defines money as a medium of exchange, recognizes the double coincidence of wants, and notes that the purchasing power of money can change. But he elaborates in the Politics. He explains there that money emerges out of barter, and he lists some of the characteristics of good money.

The Politics was translated into Latin after the Nicomachean Ethics. The translator was the Flemish Dominican William of Moerbeke (c. 1215-86), who produced two translations. The first translation was probably produced around 1255, but it was never completed. The second translation was probably completed around 1261. Although the second translation was superior to the first, Moerbeke had a rough Latin style, and his translation was generally of poor quality. Albert probably wrote his commentary on the Politics around 1263, and Aquinas probably completed his commentary in 1272 .

The French theologian and philosopher Peter John Olivi (1248-98) discovered subjective-utility theory. While Aristotle, Albert, and Aquinas were utility theorists, Olivi was the first to stress that subjective utility, not some ambiguous notion of objective utility, is relevant to price determination. Although he did not systematically treat money, Olivi used gold in his discussion of supply and demand. He realized that the price of gold is lower when there is a great abundance of it and higher when there is a lack of it. By using gold in his analysis, Olivi hinted at the quantity theory of money.

Aristotle, Albert, and Aquinas were the three founding fathers of monetary theory. But the work of Jean Buridan (1300-58) represents a huge leap forward in monetary thought. Like Albert's and Aquinas's writings, Buridan's writings on money are contained in his commentaries on the Nicomachean Ethics and the Politics. Not only does his work contain the theory of supply and demand, but he explained that money loses its value as the supply of money increases. Though Albert and Aquinas warned against debasing money, Buridan went further and argued that inflation benefits government at the expense of the people. For his contributions, Buridan can be considered the founder of the modern theory of money. Amazingly, his seminal writings on money have never appeared in English.

This brings us to the great Nicholas Oresme (1320-82). Unlike the writings of Albert, Aquinas, and Buridan, Oresme's writings on money were not commentaries on Aristotle. Thus Oresme was the first to write a treatise specifically dedicated to money. Unfortunately, however, Oresme's place in the history of monetary thought is the subject of controversy. In an effort to elevate Oresme, some scholars have argued that Buridan borrowed heavily from Oresme. Oresme was Buridan's greatest student, and some have claimed that Oresme produced his Treatise before Buridan's commentaries on Aristotle. Such scholars have downplayed the significance of Albert, Aquinas, and Buridan and have deemed Oresme the great figure in the history of monetary thought. The evidence shows that these scholars are incorrect and that it was Oresme who borrowed from his master Buridan. No one can deny the greatness of Oresme's Treatise on Money. Still, his work's status in the history of economic thought is somewhat inflated. His enduring contribution was introducing Gresham's law into economics.

There were no major contributions to monetary thought for over a century after Oresme. Europe experienced a great depression from 1340 to 1450 , and the Black Death occurred during this period. The great depression and the Black Death stifled intellectual development, including the development of monetary thought. The next great contribution to monetary thought came from Gabriel Biel (1420-95) a century and a half after Oresme. Biel followed Aristotle and Oresme, meaning he must be considered an author in the Aristotelian tradition. 
Like Oresme, he criticized inflation in the harshest possible terms and argued that any government that inflates tyrannically oppresses the people.

Nicolaus Copernicus (1473-1543) is one of the greatest figures in the history of the natural sciences, but he also made important contributions to economics. Copernicus is widely considered the first thinker to explicitly state the quantity theory of money. However, Copernicus does not seem to have gone far beyond Buridan. He argued that money loses its value through abundance and that increasing the money supply causes the price of everything to rise. However, he never seems to have stated the quantity theory as a general law. Although his Essay is a fantastic contribution with a brilliant analysis of inflation, it seems the quantity theory had not yet been achieved.

Now we come to the School of Salamanca. The great Aristotelian-Thomist Francisco de Vitoria (1483-1546), the father of international law, established the School of Salamanca in the early $1500 \mathrm{~s}$. Although he did not leave any writings on economics, Vitoria was a known advocate of the theory of supply and demand. Around this time, large quantities of precious metals began flowing into Europe from the New World. The influx of precious metals caused the purchasing power of money to decline in Europe, especially in Spain. The Spanish scholars of the School of Salamanca wanted to explain the fall in the purchasing power of money, and they were armed with Vitoria's supply-and-demand framework. The stage was set for the quantity theory of money.

The first important contribution on monetary thought from the School of Salamanca comes from Luís Saravia de la Calle (c. 1500-60). In his work Instructions for Merchants, he stated a general law: the abundance (scarcity) of goods, merchants, and money raises (lowers) prices. Here Saravia de la Calle expressed the law of supply and demand. Moreover, he included money in his formulation. He did not explicitly state the quantity theory of money, but he certainly pointed the way.

Martín de Azpilcueta (1491-1586) was the first thinker to explicitly state the quantity theory of money. As noted, thinkers such as Buridan, Oresme, Biel, and Copernicus had approached the theory. But Azpilcueta was the first to state the theory as a general law: the purchasing power, or price, of money is determined by the supply of and demand for money. Incredibly, he also explicitly stated the purchasing power parity theory of exchange rates. For his contributions, Azpilcueta must be considered one of the towering figures in the history of monetary economics. After Azpilcueta, the quantity theory was articulated by all the major economic writers in the School of Salamanca, including Tomás de Mercado (1525-75), Francisco García (f. 1583), and Luís de Molina (1535-1600).

There are two important figures outside of Spain from the sixteenth century: Sir Thomas Smith (1513-77) in England and Bernardo Davanzati (1529-1606) in Italy. Smith has been described as the first English thinker to express the quantity theory. Smith appeals to Aristotle, meaning the earliest English writings on money have Aristotelian origins. Like Smith, Davanzati is commonly labeled as an early quantity theorist. In reality, neither Smith nor Davanzati matched Azpilcueta. Still, they both realized that increasing the money supply causes the prices of all goods to rise and that this makes some people richer while making others poorer. On top of that, they argued that unnatural increases in the money supply cause economic turmoil. Hence the works of Smith and Davanzati foreshadowed monetary explanations of depressions. 
This brings us to Leonard Lessius (1552-1623). Although he was Flemish, Lessius was a Jesuit in the Spanish tradition of Vitoria, Azpilcueta, and Molina. Lessius's seminal contribution to economic science is the loanable-funds theory of the interest rate. He realized that the interest rate is the price of a loan. Since it is a price, the interest rate is determined by supply and demand on the market, or the bourse. Specifically, the interest rate is determined in the loan market by the supply of and demand for money loans. Lessius's development of the loanable-funds theory of the interest rate gives him a special place in the history of economic science.

Juan de Mariana (1536-1624) was one of history's great opponents of inflation. Following Buridan, Oresme, and Biel, he argued the purpose of money is to facilitate the exchange of goods and services. Citizens are the owners of the goods and services exchanged for money, meaning they are also the rightful owners of society's stock of money. Since government does not own society's stock of money, any government that manipulates the money supply behaves tyrannically. Not only is government inflation unjust, but it undermines trade - the foundation of society - and thereby disrupts social order. For Mariana, inflation poses an existential danger to the preservation and proliferation of humankind.

The shorter and less original contributions of Hugo Grotius (1583-1645) and Samuel Pufendorf (1632-94) bridge the gap between the Catholics and Protestants. The Flemish Jesuit Lessius played the key role in transmitting Catholic ideas on money to the Protestants in Northern Europe, and he did so through Grotius and Pufendorf. While Grotius obsessively cited all his predecessors, the Lutheran Pufendorf was fiercely anti-Catholic. Although influenced by the Catholics, he refused to cite them. Via his translator Gershom Carmichael, Pufendorf had a major influence on the thinkers of the Scottish Enlightenment, including Adam Smith. But Pufendorf's refusal to cite the Catholics, along with Smith's own disinclination to cite others, meant knowledge of the Catholic influence on Protestant economics was lost.

John Locke (1632-1704) and Dudley North (1641-91) marked the beginning of English dominance in economics. Both Locke and North explicitly stated the quantity theory of money, and both opposed inflation. Beyond that, Locke and North endorsed the loanable-funds theory of the interest rate. They argued that the interest rate, like all prices, is determined by the market forces of supply and demand. Like all price controls, attempts to fix the interest rate by law are futile. Any such attempt will create shortages, black markets, and, in the end, an even higher interest rate. As with all prices, the interest rate must be free to find its own level in the market.

Isaac Gervaise (d. 1739) was the first to explain the price-specie-flow mechanism - the most fundamental theory in international monetary economics. Gervaise wrote in the aftermath of John Law's disastrous banking experiment in France, and he developed the price-specie-flow mechanism to show that bank money causes domestic and international disequilibrium. When banks in France inflate the money supply, this will cause French prices to rise relative to prices in other nations. Higher prices in France will lead domestic and foreign buyers to purchase fewer French goods and more non-French goods. But this means gold and silver, or specie, will flow out of France and into other nations. As their reserves dwindle, French banks will be forced to contract the supply of bank money. And the contracting money supply will cause French prices to fall back toward equilibrium with other nations. In the end, banks cannot enrich the nation by increasing the money supply. 
Richard Cantillon (1680-1734) is the father of modern economics. Obviously, many thinkers wrote on economic problems before Cantillon. But these writers never viewed economics as an independent science of its own. Instead, they wrote on economic problems in connection with other subjects, such as religion, ethics, law, and politics. Cantillon's famous Essay on Economic Theory (1730) is the first book devoted entirely to economics; it is the first systematic treatment of economic science as a whole. Cantillon expressed the theory of supply and demand, the quantity theory, the loanable-funds theory, and the price-specie-flow mechanism. Beyond that, he was the first to show that banks influence the interest rate when they lend newly created money on the loan market.

Jacob Vanderlint (d. 1740) was an early advocate of the quantity theory of money in England. Like Gervaise and Cantillon, Vanderlint recognized that money creation by banks causes price inflation. Further, he articulated the price-specie-flow mechanism, and he used the mechanism to argue that money creation by banks causes mischief in foreign trade. For these reasons, Vanderlint passionately opposed bank-money inflation.

Along with his master Carmichael, Francis Hutcheson (1694-1746) was the founding father of the Scottish Enlightenment. Hutcheson's writings on money follow closely those of Grotius and Pufendorf, who were influenced by the Aristotelian-Thomists in the School of Salamanca. Although it is not original, Hutcheson's work is historically significant, for he transmitted Aristotelian ideas on money to his great students David Hume and Adam Smith.

Ferdinando Galiani (1728-87) is the grandfather of the marginal revolution of the 1870s, and his work On Money (1751) was the greatest monetary treatise of the eighteenth century. During Galiani's lifetime, the labor theory of value rose to dominance in the English-speaking world. Unlike many of his more famous English contemporaries, Galiani advocated the utility approach to value theory. He developed a marginal theory of utility and came close to expressing the law of diminishing marginal utility. Galiani applied his utility theory of value to money and, significantly, to interest. Galiani's praise of Aristotle, Aquinas, and Davanzati shows that he was firmly in the Aristotelian tradition.

David Hume (1711-76) is one of the most influential monetary theorists of all time. In philosophy, he was a thorough skeptic and opponent of natural law. However, Hume's monetary work was in the Aristotelian tradition of Grotius and Hutcheson. A staunch advocate of the quantity theory, Hume stressed that the quantity of money in society is irrelevant. Hume explained that there is no such thing as an optimal money supply; any size of the money supply is optimal. There is never any need to increase the money supply, because all it does is reduce the purchasing power of money. Hume is widely considered the first to express the price-specie-flow mechanism. Although Gervaise, Vanderlint, and Cantillon achieved it earlier, Hume deserves credit for clarifying and popularizing the theory. Finally, like Gervaise, Vanderlint, and Galiani, the quantity theory and price-specie-flow mechanism led Hume to advocate 100 percent reserve banking.

Joseph Harris (1702-64) was England's greatest authority on coinage. His large work An Essay upon Money and Coins (1757-58) represents the great consolidation of English views on money prior to Adam Smith. Here we find the quantity theory, the price-specie-flow mechanism, and a critique of bank money. A fierce opponent of inflation, he insisted that the standard of money must never be altered under any circumstances. Finally, like Hume, he advocated 100 percent reserve banking. 
A.R.J. Turgot (1727-81) and Étienne Bonnot de Condillac (1714-80) were two of the most significant French economists of the eighteenth century. Turgot's greatest contributions to economics were in the area of interest. He stated the loanable-funds theory of the interest rate with greater clarity than any of his predecessors, and his work on interest was not surpassed until after the marginal revolution of the 1870s. Condillac published his great work Commerce and Government in 1776, just one month before Adam Smith published The Wealth of Nations. Along with Cantillon's Essay, Condillac's work is the most important general treatise on economics in the period before The Wealth of Nations. Turgot and Condillac relied greatly on Cantillon. Cantillon had drawn on Locke, who had been heavily influenced by Grotius, who in turn was heavily influenced by the Aristotelian-Thomists in the School of Salamanca. All this means that there is a line from Turgot and Condillac all the way back to Aristotle.

Adam Smith is widely considered the father of economics. However, the writings in this volume should make one point abundantly clear: Smith did not singlehandedly invent economics. There were many important economic thinkers who came before Smith, and it could be argued that, on certain points, some earlier thinkers were more advanced than Smith. This is not to diminish Smith's role in the history of economic science. He is a central figure. It just means that Smith did not invent economics out of whole cloth. He was familiar with the economic thought of Grotius, Locke, Hutcheson, Cantillon, Hume, and Turgot. Through these authors, the Aristotelian tradition influenced Adam Smith.

Unfortunately, however, Smith departed from the Aristotelians by adopting the problematic labor theory of value rather than the utility theory. Hutcheson was Smith's teacher, and Hutcheson passed down the Aristotelian utility theory to Smith. Indeed, we find the utility theory of value in Smith's lectures. Smith's adoption of the labor theory of value in The Wealth of Nations represented a step back from the utility theory advocated by the Aristotelians that came before. In short, we find the greatest problem in Smith's work precisely where he deviated most from the Aristotelian tradition. The problematic labor theory of value created problems for his theory of money and banking.

The following pages contain the most important writings on monetary thought from Aristotle up to the time of Adam Smith. Regrettably, many of these writings have remained inaccessible to those interested in monetary thought. This volume makes these inaccessible contributions available in one convenient place. 